\title{
Karakteristik Usaha Mikro, Kecil dan Menengah Dalam Mengelola Keuangan di Desa Gunung Sindur, Kabupaten Bogor
}

\author{
Ani Rakhmanita
}

Univesitas Bina Sarana Informatika
e-mail: anirakhmanita@upi.edu

\begin{tabular}{ccc}
\hline Diterima & Direvisi & Disetujui \\
$16-08-2021$ & $29-08-2021$ & $01-09-2021$ \\
\hline
\end{tabular}

\begin{abstract}
Abstrak Pasca merebaknya pandemi-Covid-19, UMKM kini menjadi andalan semua pihak untuk mendukung perekonomian nasional. Namun, pelaku UMKM dalam berusaha dilakukan secara tradisional sehingga usahanya tidak berkembang pesat. Adapun salah satu masalah yang dihadapi pelakunya terutama pada pengelolaan keuangan yang belum teradministrasi dengan baik, yang mengakibatkan usahanya menghadapi banyak kendala. Masyarakat di desa Gunung Sindur mengalami kondisi yang sama. Untuk itu, perlu dilakukan penelitian karakteristik pelaku UMKM di desa Gunung Sindur. Kabupaten Bogor dalam mengelola keuangan usahanya. Metode yang digunakan pada penelitian ini pada dasarnya adalah mendeskripsikan dan menganalisis sikap dan pemikiran seseorang ataupun sekelompok orang, tanpa menguji suatu hipotesis dan hanya ingin mengetahui keadaan variabel secara lepas serta tidak menghubungkan antar variabel yang satu dengan variabel yang lainnya. Penelitian ini menggunakan 24 responden UMKM di wilayah Gunung Sindur yang dipilih secara acak. Penelitian ini menggunakan statistik deskriptif sederhana untuk mengolah data dari angket yang disebarkan untuk mengetahui tingkat pengetahuan pengelolaan keuangan UMKM di desa Gununung Sindur. Hasil dari penelitian ini menunjukkan bahwa tingkat pengelolaan keuangan dari responden rendah. Hal ini tercermin berdasarkan hasil yang diperoleh: Prosentase penerapan indikator pengelolaan keuangan yang paling tinggi diterapkan adalah indikator Perencanaan keuangan (76\%), Pencatatan keuangan (64\%), Pengendalian (48\%\%) dan Pelaporan keuangan $(24 \%)$. Pelaku UMKM perlu meningkatkan ketrampilan pelaporan keuangannya baik secara formal maupun informal dengan melakukan kerjasama bersama pemerintah, institusi terkait dan perguruan tinggi.
\end{abstract}

Kunci : Akuntansi, Covid-19, Pengelolaan Keuangan, UMKM, Wirausaha

ABSTRACT-After the outbreak of the Covid-19 pandemic, MSMEs are now the mainstay of all parties to support the national economy. However, SMEs in trying to do it traditionally so it does not develop rapidly. As for one of the problems faced by the perpetrators, especially in financial management that has not been properly administered, which resulted in facing many obstacles. The community in Gunung Sindur village experienced the same condition. For this reason, it is necessary to research the characteristics of SME actors in Gunung Sindur village. Bogor Regency in managing finances The method used in this study is basically to describe and analyze the attitudes and thoughts of a person or group of people, without testing a hypothesis and only wanting to know the state of the variables independently and not connecting one variable to another variable. This study used 24 respondents from SME in the Gunung Sindur area who were randomly selected. This study uses simple descriptive statistics to process data from questionnaires distributed to determine the level of knowledge of MSME financial management in the village of Gununung Sindur. The results of this study indicate that the level of financial management of the respondents is low. This is based on the financial results obtained: The percentage of the most applied financial management indicators are financial planning indicators (64\%), control (48\% \%) and financial reporting (24\%). SME actors need to improve their financial reporting informally by collaborating with the government, related institutions and universities.skills both formally and

Keywords: acoounting, covid-19, entrepreneur, financial managemet, sme

\section{PENDAHULUAN}

Corona Virus Disease 2019 merupakan virus yang dapat menginfeksi saluran pernapasan pada Manusia, Adapun gejalanya dimulai dari gejala batuk pilek hingga yang berdampak serius seperti Middle East Respiratory Syndrome (MERS) dan Severe Acute Respiratory Syndrome (SARS). Virus covid-19 ini mudah menular melalui droplet yang keluar ketika seseorang terkonfirmasi positif (WHO, 2020). Berdasarkan data Per 30 desember 2020 pada laman www.covid19.go.id/, kasus Covid di Indonesia bertambah sebesar 1.031 kasus dan belum menunjukkan tanda-tanda penurunan atau melandai. Jawa Timur, DKI Jakarta dan Jawa Barat merupakan daerah yang penduduknya padat menjadi sentra penyebaran penderita Covid-19 terbesar di Indonesia. Untuk itu, perlu adanya kerjasa antara 
pemerintah dan masyarakat dalam mengatasi pandemi ini.

Akibat pandemi Covid-19, berdampak besar pada kesehatan dan perekonomian negara. Kesemuanya, akibat kebijakan yang dilakukan pemerintah untuk mengatasi pandemi, telah merubah perilaku masyarakat dalam berkonsumsi, sehingga berdampak pada pendapatan masyarakat. Kebijakan ini, secara umum dilakukan negara lain, Indonesia yang merupakan bagian dari negara G20, mengalami kondisi yang sama, sehingga Menteri Keuangan Republik Indonesia, Ibu Sri Mulyani dalam acara Town Hall Meeting 2020 pada tanggal 19 Juni 2020, menyatakankan bahwa Indonesia akan menghadapi ujian yang sangat berat pada pertumbuhan ekonomi di kwartal II, diprediksi akan mengalami minus sebesar 3,8\%. Lesunya perekonomian ini akan berdampak pada kegiatan usaha mikro, kecil, dan menengah. Tercatat beberapa usaha mikro, kecil dan menengah mengalami penurunan pendapatan dan kebangkrutan Untuk itu, Dalam upaya mengatasi dampak dari pembatasan sosial berskala besar sebanyak 38 persen dari usaha mikro, kecil dan menengah mengantasipasikannya dengan mengurangi stok barangnya. Namun, sebanyak 16 persen dari usaha mikro, kecil dan menengah akibat tokonya ditutup mengambil kebijakan dengan mengurangi jumlah karyawannya (Wachyu \& Winarto, 2020)

Perilaku masyarakat yang berubah dalam berkonsumsi akibat pandemi, membuat para pelaku usaha mikro, kecil dan menengah perlu mencari cara baru yang dapat membangkitkan kembali perekonomian yang lesu pasca pandemik covid ini. Salah satu cara yang dapat digunakan dalam menata kembali kehidupan demi masa depan bangsa ini adalah melalui pengeloaan keuangan untuk keberlangsungan usaha bagi para pelaku usaha mikro dan menengah. Tujuan dari pengelolaan keuangan adalah keberlangsungan usaha yang meliputi: terpenuhinya kebutuhan modal usaha, mempunyai cadangan untuk keperluan yang urgent di masa yang sulit, dan untuk kepentingan investasi (Luzuardi, 2011). Pengelolaan keuangan yang baik dapat mempercepat pemulihan usaha mikro, kecil dan menengah. Hal ini, dapat meningkatkan pendapatan pemerintah dari sektor pajak, yang dapat digunakan untuk membiayai kebutuhan infrastruktur dan pelayanan public.

Kebanyakan pelaku usaha yang kesulitan keuangan bukan karena sumber daya keuangannya kecil, tetapi disebabkan kurang tepat dalam mengelola sumber daya keuangan. Hal ini menguatkan pentingnya pengeloalaan keuangan bagi pelaku usaha mikro kecil dan menengah. Pengeloaan keuangan merupakan pemahaman konsep dasar keuangan tentang sumber daya keuangan dan pengalokasian sumber daya keuangan tersebut secara efektif dan efisien untuk keamananan keuangan. Pengelolaan keuangan yang baik menjadi salah satu aspek penting bagi pertumbuhan usaha mikro kecil dan menengah. Beberapa penelitian telah banyak mengkonfirmasi bahwa kemampuan perusahaan dalam mengenali dan mengakses sumber daya keuangan akan berdampak pada tingkat pertumbuhan usaha. Dalam penelitiannya (Bongomin dkk, 2017) mengungkapkan bahwa hubungan antara pengetahuan keuangan dan pertumbuhan usaha kecil dan menengah di negara berkembang, seperti Uganda berpengaruh positif dan signifikan. Studi tersebut menyoroti pengelolaan keuangan diperlukan untuk pertumbuhan usaha kecil dan menengah di negara berkembang. Dalam penelitiannya juga ditemukan bahwa pemilik usaha dapat mengikuti pelatihan pengeloaan keuangan yang disediakan oleh organisasi pengembangan keterampilan kewirausahaan untuk mendapatkan pengetahuan dan keterampilan keuangan, yang nanti nya dapat membuat keputusan dan pilihan keuangan yang bijaksana dan lebih baik. Hasil studi (Das \& Dey, 2005) menjelaskan bahwa pengaruh positif dari pengelolaan keuangan menjadi suatu faktor kunci keberhasilan usaha mikro kecil dan menengah dan dapat digunakan untuk mempertahankan keberlanjutan usahanya.

Pasca merebaknya pandemi-Covid-19, UMKM kini menjadi andalan semua pihak untuk mendukung perekonomian nasional. Namun, pelaku UMKM dalam berusaha dilakukan secara tradisional sehingga usahanya tidak berkembang pesat. Adapun salah satu masalah yang dihadapi pelakunya terutama pada pengelolaan keuangan yang belum teradministrasi dengan baik, yang mengakibatkan usahanya menghadapi banyak kendala. Masyarakat di desa Gunung Sindur mengalami kondisi yang sama. Untuk itu, perlu dilakukan penelitian karakteristik pelaku UMKM di desa Gunung Sindur. Kabupaten Bogor dalam mengelola keuangan usahanya.

\section{METODE PENELITIAN}

Penelitian yang dilakukan di desa Gunung Sindur Kabupaten Bogor, dengan objek pelaku usaha mikro,kecil dan menengah dan diperoleh responden sebanyak 24 pelaku usaha, yang pengambilan sampenya dilakukan dengan metode purposive sampling. Penelitian ini bertujuan untuk mengetahui karakteristik pelaku UMKM di desa Gunung Sindur dalam mengelola keuangan usahanya. Metode yang digunakan statistik deskriptif dengan memberikan gambaran dari dari karakteristik dari pelaku UMKMnya. Karakteristik yang didapatkan kemudian dilakukan analisis secara kualitatif, agar dapat menambah informasi dan kebijakan yang dapat diambil untuk mengembangkan UMKM di daerah tersebut. Metode yang digunakan pada penelitian ini pada dasarnya adalah mendeskripsikan dan menganalisis sikap dan pemikiran seseorang ataupun sekelompok orang, tanpa menguji suatu hipotesis dan 
hanya ingin mengetahui keadaan variabel secara lepas serta tidak menghubungkan antar variabel yang satu dengan variabel yang lainnya. Sehingga jenis penelitian ini merupakan penelitian kualitatif dengan pendekatan deskriptif. Penulis melakukan penelitian dengan metode ini dikarenakan sesuai dengan sifat dalam mengelola keuangan usaha.yaitu untuk memperoleh gambaran tentang pengelolaan keuangan para informan. Metode analisis desktiptif kualitatif adalah mengambarkan dan menganalisa kondisi dan situasi dari berbagai data yang dikumpulkan di lapangan mengenai masalah yang akan diteliti (Winartha, 2006). Metode penelitian kualitatif berlandaskan pada filsafat positivisme, digunakan untuk meneliti kondisi obyek yang alamiah, (berlawanan dengan eksperimen). Peneliti sebagai instrument kunci dimana teknik analisis data bersifat induktif yang lebih menekankan makna dari pada generalisasi (Sugiyono, 2015).

Teknik pengumpulan data disesuaikan dengan masalah dan tujuan dari penelitian ini, agar diperoleh data penelitian yang akurat dan valid. Penulis menggunakan pengumpulan data melalui wawancara, angket dan pengamatan (Sugiyono, 2017). Angket berupa Google form dibagikan kepada para pelaku usaha mikro kecil dan menengah dari berbagai sektor usaha. Komponen dalam angket terdiri dari 12 pertanyaan. Angket yang dibagikan berisi tentang Pengelolaan keuangan para pelaku usaha mikro, kecil dan menengah di desa Gunung Sindur mengacu pada empat indikator, antaralain: penggunaan anggaran, pencatatan, pelaporan, dan pengendalian (Kuswadi, 2005). Jenis angket yang gunakan dalam penelitian ini adalah angket tertutup, dimana informan hanya memberi tanda pada kolom jawaban yang sesuai. Kemudian, data yang terkumpul dari angket tersebut ditampilkan dalam bentuk tabel yang selanjutnya akan dianalisa. Analisis data yang digunakan penulis adalah Statistika deskriptif. Statistik deskriptif bersifat sangat sederhana, dalam arti tidak menggeneralisasikan hasil penelitian, tetapi hanya menghitung persentase suatu jawaban terhadap angket penelitian (Arikunto, 2015). Adapun manfaat yang diperoleh dengan metode ini akan diperoleh informasi karakteristik kontribusi dari para pelaku UMKM.

\section{HASIL DAN PEMBAHASAN}

Penelitian ini, dilakukan di desa Gunung Sindur Bogor dengan objek pelaku usaha mikro, kecil dan menengah. Dalam penelitian ini, diperoleh responden sebanyak 24 pelaku UMKM di desa Gunung Sindur Kabupaten Bogor, dengan responde yang berjenis kelamin pria sebanyak 67 persen dan wanita sebanyak 33 persen. Pendidikannya terdapat sebanyak persen SLTA, persen Akademi atau sarjana, persen SLTP, persen SD, dengan memiliki usaha selama lima tahun atau kurang sebanyak 45 persen, 11-15 tahun sebanyak 28 persen, 6-10 tahun sebanyak 23 persen, 16 tahun atau lebih sebanyak 4 perpen. Informasi ini dapat memberikan gambaran bahwa persentase dari jenis kelamin dan lulusan pendidikan memberikan kontribusi terhadap lamanya usaha. Hal ini, terkait dengan pria sebagai kepala rumah tangga bertanggung jawab terhadap kehidupan keluarga, sehingga mereka berupaya semaksimal mungkin untuk tetap mencari nafkah dengan melakukan usahanya, dan pendidikan akan mempengaruhi ketrampilan dan kretifitas dari pelaku usahanya, sehingga semakin tinggi pendidikannya akan mempermudah pelaku usaha dalam mengembangkan usahanya. Untuk itu, jenis kelamin dan pendidikan yang ada sesuai dengan lamanya usaha dari pelaku UMKM.

Dalam pengukuran anggaran menggunakan 4 indikator. Adapun indikator yang digunakan berupa penggunaan anggaran, pencatatan akuntansi, pelaporan keuangan dan pengendalian (Kuswadi, 2005).Pada masing-masing indikator menggunakan sebanyak 5 pertanyaan yang dapat menggambarkan kondisi dari karakteristik pelaku UMKM.

(Kuswadi, 2005).

Tabel 1. Penggunaan Anggaran

\begin{tabular}{clcc}
\hline \multirow{2}{*}{$N$} & \multicolumn{1}{c}{ Indikator } & \multicolumn{2}{c}{$\%$} \\
\cline { 3 - 4 } & & Ya & Tidak \\
\hline $\mathbf{1}$ & $\begin{array}{l}\text { Saya Membuat } \\
\text { rencana keuangan } \\
\text { untuk setahun }\end{array}$ & 80 & 20 \\
\hline $\mathbf{2}$ & $\begin{array}{l}\text { Saya membuat } \\
\text { rencana penjualan } \\
\text { dalam usaha }\end{array}$ & 100 & 0 \\
\hline $\mathbf{3}$ & $\begin{array}{l}\text { Saya membuat } \\
\text { rencana laba yang } \\
\text { diinginkan }\end{array}$ & 40 & 60 \\
\hline $\mathbf{4}$ & $\begin{array}{l}\text { Saya membuat } \\
\text { rencana keuangan } \\
\text { untuk masa depan }\end{array}$ & 60 & 40 \\
\hline $\mathbf{5}$ & $\begin{array}{l}\text { Saya mempunyai } \\
\text { cadangan kas untuk } \\
\text { pengeluaran tidak } \\
\text { terduga }\end{array}$ & 100 & 0 \\
\hline & Rata-rata & $\mathbf{7 6 \%}$ \\
\hline
\end{tabular}

Sumber: Data diolah 2021

Pelaku UMKM yang melakukan penerapan penggun aan anggaran sudah sebanyak 76 pesen. Adapun pen yebabknya yang sebanyak 24 persen tidak menerapk annya karena mereka menganggap usahanya masih $\mathrm{k}$ ecil sehingga tidak perlu membuat perencanaan pem biayaan dan target laba penjualan. Jadi, bagi mereka yang terpenting setiap harinya ada pembeli dan dana nya dapat digunakan untuk memenuhi kehidupannya

Pada penggunaan anggaran, pelaku UMKM kebayanyakan melakukan perencanaan penjualan dan 
cadangan kas, setalah itu mereka baru melakukan perencanaan keuangan untuk masa depan dan kemudian diikuti dengan perencana laba sesuai dengan yang diinginkan. Namun, dengan pendidikan yang dimilikinya, para pelaku usahanya memiliki keterbatasan, sehingga mereka belum dapat membuat penggaraan dengan baik, dimana kebanyakan responden hanya berpikir keuntungan untuk hari ini saja tanpa mempersiapkan keuntungan jangka panjang, sehingga menyebabkan usaha stagnan dan tidak berkembang. Hasil pada penelitian ini sejalan dengan (Karadag, 2015) yang menyatakan bahwa perusahaan kecil dan menengah dihadapkan pada sejumlah tantangan masalah yang timbul dari pengelolaan keuangan yang buruk, dilaporkan sebagai penyebab utama kegagalan bisnis usaha kecil menengah. Untuk itu, pelaku usaha perlu memiliki kemampuan dalam meningkatkan ketrampilan pengelolaan keuangan, agar usahanya dapat berkembang dengan baik.

\section{Tabel 2. Pencatatan Akuntansi}

\begin{tabular}{clcc}
\hline No & \multicolumn{1}{c}{ Indikator } & \multicolumn{2}{c}{$\%$} \\
\cline { 3 - 4 } & & Ya & Tidak \\
\hline $\mathbf{1}$ & $\begin{array}{l}\text { Saya Membuat pencatatan } \\
\text { transaksi secara rutin }\end{array}$ & 60 & 40 \\
\hline $\mathbf{2}$ & $\begin{array}{l}\text { Saya membuat pencatatan } \\
\text { transaksi penjualan }\end{array}$ & 80 & 20 \\
\hline $\mathbf{3}$ & $\begin{array}{l}\text { Saya membuat pencatatan } \\
\text { transaksi pembelian }\end{array}$ & 80 & 20 \\
\hline $\mathbf{4}$ & $\begin{array}{l}\text { Saya melakukan } \\
\text { rekapitulasi penerimaan } \\
\text { kas }\end{array}$ & 60 & 40 \\
\hline $\mathbf{5}$ & $\begin{array}{l}\text { Saya melakukan } \\
\text { rekapitulasi pengeluaran } \\
\text { kas }\end{array}$ & 40 & 60 \\
\hline & Rata-rata & $\mathbf{6 4 \%}$ & \\
\hline
\end{tabular}

Sumber: Data diolah 2021

Pencatatan akuntansi sebanyak 64 persen sudah diterapkan pelaku UMKM, tetapi sebanyak 36 persen belum menerapkannya. Pelaku UMK yang melaksanakan pencatatan kebanyakan digunakan untuk transaksi penjualan dan pembelian, kemudian transaksi rutin dan rekapitulasi pembelian, selanjutnya baru rekapitulasi pengeluaran.

Bila dilihat pelaku UMKM yang belum menerapkan pencatatan akuntansi karena mereka lebih terkonsentrasi pada produksi dan pemasaran. Hal ini, akibat adanya anggapan dari pelaku UMKM bahwa keberlangsungan usaha hanya bergantung pada produksi dan pemasaran. Kondisi ini, sejalan dengan penelitian yang dilakukan Margani (2007) bahwa pencatatan akuntansi dianggap tidak penting, tetapi sebenarnya dengan menerapkan pencatatan akuntansi justru akan memudahkan pelaku UMKM untuk mengetahui perkembangan dan kendala usaha yang dihadapinya.

Tabel 3. Pelaporan keuangan

\begin{tabular}{clcc}
\hline No & \multicolumn{1}{c}{ Indikator } & \multicolumn{2}{c}{$\%$} \\
\cline { 2 - 4 } & & Ya & Tidak \\
\hline $\mathbf{1}$ & $\begin{array}{l}\text { Saya Membuat laporan } \\
\text { keuangan untuk menilai } \\
\text { kemajuan usaha }\end{array}$ & 20 & 80 \\
& & \\
\hline $\mathbf{2}$ & Saya membuat neraca & 20 & 80 \\
\hline $\mathbf{3}$ & $\begin{array}{l}\text { Saya membuat laporan arus } \\
\text { kas }\end{array}$ & 40 & 60 \\
\hline $\mathbf{4}$ & $\begin{array}{l}\text { Saya melakukan laporan } \\
\text { laba rugi }\end{array}$ & 40 & 60 \\
\hline $\mathbf{5}$ & $\begin{array}{l}\text { Saya membuat laporan } \\
\text { keuangan lengkap }\end{array}$ & 0 & 100 \\
\hline & Rata-rata & $\mathbf{2 4 \%}$ & \\
\hline
\end{tabular}

Sumber: Data diolah 2021

Pada tabel 3 diketahui bahwa persentase penerapan pelaporan keuangan adalah sebesar $24 \%$. Pada setiap indikator yang ada seperti membuat laporan keuangan untuk menilai kemajuan usaha, membuat laporan neraca, laporan laba rugi dan laporan arus kas terlihat sangat sedikit sekali yang membuat laporan keuangan. Banyaknya pelaku usaha tidak melakukan pelaporan keuangan karena mereka menganggap usahanya masih kecil, sehingga tidak diperlukan laporan keuangan. Namun, mereka menganggap kondisi dari usahanya dapat dilihat dari pencatatan akuntansi saja. Hasil ini, sesuai dengan penelitian yang dilakukan Jati (2004) yang menyatakan bahwa kebanyakan dari pemilik usaha mikro, kecil dan menengah hanya mencatat penerimaan dan pengeluaran dengan format yang sesuai dengan keinginan mereka saja dan untuk mempekerjakan seseorang yang ahli dalam bidang akuntansi. Namun, pencatatan keuangan sederhana tanpa membuat laporan keuangan akan menghambat pelaku usaha mikro, kecil dan menengah dalam memenuhi persyaratan dalam pengajuan penambahan modal di bank, karena ketidakmampuan dalam menyediakan informasi yang diperlukan oleh bank tersebut (Cziráky dkk, 2005). Laporan keuangan diperlukan oleh pelaku usaha Mikro kecil dan menengah sebagai sebuah informasi akuntansi yang mempunyai peranan penting dalam pencapaian keberhasilan usaha. Selain itu juga, laporan keuangan dapat dijadikan dasar informasi akuntansi yang andal dalam pengambilan keputusan ekonomis seperti, pengembangan pasar, penetapan harga jual, untuk mengetahui laba atau rugi yang sesungguhnya dan pengendalian aset, kewajiban serta modal. 
Tabel 4. Pengendalian

\begin{tabular}{lllc}
\hline No & \multicolumn{1}{c}{ Indikator } & \multicolumn{2}{c}{$\%$} \\
\cline { 3 - 4 } & & Ya & Tidak \\
\hline $\mathbf{1}$ & $\begin{array}{l}\text { Saya memiliki prosedur untuk } \\
\text { pengeluaran kas }\end{array}$ & 40 & 60 \\
\hline $\mathbf{2}$ & $\begin{array}{l}\text { Saya mengarsipkan nota dari } \\
\text { penggunaan kas yang } \\
\text { dikelurkan }\end{array}$ & 80 & 20 \\
\hline $\mathbf{3}$ & $\begin{array}{l}\text { Saya mengarsipkan nota } \\
\text { penjualanan }\end{array}$ & 60 & 40 \\
\hline $\mathbf{4}$ & $\begin{array}{l}\text { Saya memisahkan antara uang } \\
\text { pribadi dan modal usaha }\end{array}$ & 20 & 80 \\
& $\begin{array}{l}\text { Saya melakukan evaluasi } \\
\text { antara rencana dan aktual }\end{array}$ & 40 & 60 \\
\hline $\mathbf{5}$ & Rata-rata & $\mathbf{4 8 \%}$ & \\
\hline
\end{tabular}

Sumber: Data diolah 2021

Tabel 4. di atas menjelaskan rata-rata tingkat pengendalian keuangan responden pada katagori cukup atau sedang dengan nilai rata-rata $48 \%$. Hal tersebut menunjukkan bahwa pengendalian pelaku usaha di desa gunung sindur relatif belum optimal dan harus lebih ditingkatkan lagi. Bila dilihat dari setiap indikator, maka terlihat bahwa sebanyak $40 \%$ dari responden, tidak memiliki nota dan sebanyak $40 \%$ tidak melakukan evaluasi antara rencana keuangan dengan aktual. Pengendalian banyak yang tidak dilakukan pelaku UMKM karena mereka tidak paham terhadap prosedur pengeluaran kas dan pentingnya arsip nota sebagai historis data keuangan. Menurut (Mulyadi, 2014) Fungsi pengendalian adalah sangat penting bagi perusahaan, karena dengan prosedur pengawasan yang professional akan memiliki dampak yang produktif bagi usaha. Untuk itulah perusahaan harus memiliki konsep pengendalian keuangan yang baik dengan berbagai pendekatan dan prosedur yang jelas, sehinga dapat membantu dalam menaikkan kinerja perusahaan. Pelaku UMKM di desa Gunung Sindur Kabupaten Bogor sudah banyak yang menyadri pentingnya melaukan pengelolaan keuangan untuk usahanya. Namun, terdapat beberapa yang masih belum menyadari hal tersebut. Kesemuanya itu, tidak terlepas dari latar belakang pendidikan dan lamnya usaha yang dimiliki. UMKM yang menerapkan pengelolaan keuangan sebagian besar melakukannya untuk penggunaan anggaran sebanyak 76 persen, pencatatan akuntansi sebanyak 64 persen, pengendalian sebanyak 48 persen, dan pelaporan keuangan sebanyak 24 persen. Untuk itu, pada pelaku UMKM ini sebaiknya meningkatkan pendidikan secara formal dan informal. Kegiatan ini perlu dilakukan karena dengan memiliki ketrampilan pengelolaan keuangan akan membuat usahanya semakin pesat, mengingat kendala yang dihadapi semakin berkurang. Pihak pemerintah daerah dapat melakukan kerjasama dengan institusi terkait UMKM dan perguruan tinggi untuk secara bersama-sama dapat membina dengan memberikan pelatihan kepada pelaku UMKM agar dapat meningkatkan ketrampilan pengelolaan keuangan guna meningkatkan usahanya

\section{KESIMPULAN}

Berdasarkan hasil penelitian terkait pengelolaan keuangan untuk keberlangsungan usaha pada masa pandemic covid-18 di desa Gunung Sindur, maka dapat ditarik suatu kesimpulan sebagai berikut: Para pelaku usaha mikro, kecil dan menengah memiliki pengetahuan umum yang rendah mengenai pengelolaan keuangan. Pelaku usaha mikro, kecil dan menengah di desa Gunung Sindur, Kabupaten Bogor dalam pengelolaan keuangan kebanyakan dilakukan secara tradisional, sehingga usahanya tidak dapat berkembang dengan pesat. Kesemuanya, tidak terlepas dari pendidikan dan lamanya usaha yang mereka jalankan, serta pelakunya yang mayoritas pria dalam menjalankan usahanya hanya sebatas pada kewajiban untuk mencari nafkah untuk hari itu saja. Namun, terdapat beberapa pelaku yang telah menyadari betapa pentingnya melakukan pengelolaan keuangan untuk kemajuan usahanya. Adapun karakteristik dari pelaku UMKM di daerah ini yang menerapkan pengelolaan keuangan, sebagian besar diprioritaskan pada penggunaan anggaran, pencatatan akuntansi, pengendalian, dan pelaporan keuangan. Prioritas yang dilakukan menunjukkan bahwa pengelolaan keuangan yang dilakukan masih diprioritaskan untuk jangka pendek dan hanya sebagian kecil yang sudah memikirkan untuk jangka menengah dan panjang. Untuk itu, pelaku UMKM perlu meningkatkan ketrampilan pelaporan keuangannya baik secara formal maupun informal dengan melakukan kerjasama bersama pemerintah, institusi terkait dan perguruan tinggi. Pada peneliti selanjutnya, sebaiknya menggali informasi lain dari karakteristik pelaku UMKM, terutama terkait agar mereka dapat sadar dan memotivasi betapa pentingnya manfaat dari pelaporan keuangan dalam mengembangkan, serta metode yang tepat digunakan untuk mentransfer pengetahuan ketrampilan pengelolaan keuangan yang sesuai dengan budaya setempat agar dapat mudah dipahami pelaku UMKM.

\section{REFERENSI}

Arikunto. (2015). Prosedur Penelitian Suatu Pendekatan Praktik. Rineka Cipta.

Cziráky, D., S. Tiśma, and A. Pisarović, . (2005). Determinant of Low Approval Rate In Croatia. Small Business Economic, 25, 347-37.

Das, A.K,. N B Dey, . (2005). Financial Management and Analysis Practices in Small Business: An Exploratory Study in India. Working Paper.

Jati, H., B. Bala, dan O. Nisnoni,. (2004). Menumbuhkan Kebiasaan Usaha Kecil 
Menyusun Laporan Keuangan. Jurnal Bisnis Dan Usahawan, II (8), 21.

Jindrichovska, Irena, . (2014). Financial management in SMEs. European Research Studies Journal, 16(4), 79-95. https://doi.org/10.35808/ersj/405

Karadag, H. (2015). Financial Management Challenges In Small And Medium-Sized Enterprises: A Strategic Management Approach. EMAJ: Emerging Markets Journal, 5(1), 26-40. https://doi.org/10.5195/emaj.2015.67

Kuswadi. (2005). Cara Mudah Memahami Angka dan Manajemen Keuangan bagi Orang Awam. Elex Media Komputindo.

Luzuardi. (2011). Financial Literacy Around the Word An Oveview National Bureau of Economic Research. NBER Working Paper, 17 (170).

Margani, Pinasti, . (2007). Pengaruh Penyelenggaraan dan Penggunaan Informasi Akuntansi terhadap Persepsi Pengusaha kecil atas Informasi Akuntansi: Suatu Riset Eksperimen. Jurnal Riset Akuntansi Indonesia, Vol.10,No.

Mulyadi. (2014). Akuntansi Biaya (Edisi ke-5). UPPSTIM YKPN.

Okello Candiya Bongomin, G., Mpeera Ntayi, J., Munene, J. C., \& Akol Malinga, C. (2017). The relationship between access to finance and growth of SMEs in developing economies. Review of International Business and Strategy, 27(4), 520-538. https://doi.org/10.1108/RIBS04-2017-0037

Shehu, A. M., Aminu, I. M., Mat, K. N., Nasiru, A., Johnson, Popoola Oluwatoyin Tsagem, M. M., \& Kura, Kabiru Maitama, . (2013). The Mediating Effect between Some Determinants of SME Performance in Nigeria. Management, $3(4)$, 237-242. https://doi.org/10.5923/j.mm.20130304.07

Sugiyono. (2015). Metode Penelitian Kombinasi (Mix Methods). Alfabeta.

Sugiyono. (2017). Metode Penelitian Kuantitatif, Kualitatif, dan $R \& D$. Alfabeta.

Wachyu, W., \& Winarto, A. (2020). Pengaruh Knowledge Management Terhadap Peningkatan Kinerja UMKM Dengan Kompetensi Sebagai Variabel Moderasi. 3(2), 141-157.

The World Health Report 2020, (2020).

Winartha, Made, . (2006). Metodologi Penelitian Sosial Ekonomi. Andi Ofsset. 